\title{
INTRODUCTION: \\ REVIEW SYMPOSIUM ON GIOVANNI ARRIGHI'S ADAM SMITH IN BEIJING
}

\author{
Thomas D. Hall \\ Book Review Editor
}

\begin{abstract}
About sixteen months ago we began discussing commissioning a series of review essays on Arrighi's Adam Smith in Beijing. The original idea was to publish a collection of essays from various world-systems scholars, and have Arrighi respond. As we all know, Giovanni became ill and sadly passed in summer of 2009. In commissioning the essays as book review editor I faced a special challenge. Some likely writers had already committed to essays for other venues (e.g., Janet Abo-Lughod 2008; Chris Chase-Dunn forthcoming). I also wanted to get a variety of approaches so that the entire collection would represent a diverse set of views. The following essays do that. We are especially fortunate to have an essay from Robert Denemark, who I asked

to comment on Andre Gunder Frank's probable take(s) on Adam Smith in Beijing. The remaining essays offer various insights into this important work.
\end{abstract}

\section{REFERENCES}

Abu-Lughod, Janet. 2008. Review of Arrighi's Adam Smith in Beijing. Trajectories 20(1):15-18. Chase-Dunn, Christopher. Forthcoming. "Adam Smith in Beijing: A World-Systems Perspective." Historical Materialism. 